IJJM

Ilomata International Journal of Management

P-ISSN: 2714-8971; E-ISSN: 2714-8963

Vol. 1 No. 2 March 2020 pp. 51-58

https://www.ilomata.org/index.php/ijim

\title{
Bankruptcy Prediction Analysis Using the Altman Z-Score Method at PT Aneka Tambang (Persero) Tbk
}

\author{
Iis Fitriani ${ }^{1}$, Puji Muniarty ${ }^{2 *}$ \\ ${ }^{12}$ Management Program, Bima School of Economics, Bima City \\ Correspondent: puji.stiebima@gmail.com
}

\begin{abstract}
This study aims to determine the prediction of bankruptcy in Aneka Tambang (Persero) Tbk for the period 2011 to 2018. Z-score is the independent variable $(\mathrm{X})$ measuring by five ratios: working capital to total assets, retained earnings to total assets, earnings before interest and tax to total assets, the market value of equity to total liabilities, and sales to total assets. The background of this research is the government's ban on the export of raw minerals, which resulted in Aneka Tambang (Persero) Tbk no longer making overseas sales of nickel ore, which made the company's profit decline. This research method uses descriptive research with a quantitative approach, the source of the data used is secondary data based on financial reports published on the Indonesia Stock Exchange and the official website www.antam.com. The population used is the financial statement data for ten years, namely from 2009 to 2018, while the sample using for eight years, namely from 2011 to 2018. The data collection technique carried out using documentation and literature study techniques. Data analysis techniques were carried out by discriminant analysis using the Altman Z-Score method and one sample t-test analysis. The Altman Z-Score uses five variables that represent liquidity ratios X1, profitability ratios $\mathrm{X} 2$ and $\mathrm{X} 3$, and activity ratios $\mathrm{X} 4$, and $\mathrm{X} 5$. The formula Z-Score $\mathrm{Z}=0.717 \mathrm{X} 1+0.847 \mathrm{X} 2$ $+3.107 \mathrm{X} 3+0.420 \mathrm{X} 4+0.998 \mathrm{X} 5$. With criteria, $\mathrm{Z}>2.99$ categorized as a good company. Z between 1.23 to 2.99 categorized as a company in the grey area or area of financial difficulty. $\mathrm{Z}$ $<1.23$ is categorized as a potentially bankrupt company.
\end{abstract}

Keywords: Bankruptcy, Altman Z-Score, Aneka Tambang (Persero) Tbk.

\section{INTRODUCTION}

Indonesia is a country with abundant natural resources, especially those contained in the earth's base. Unfortunately, until now, the mining sector in Indonesia has not yet developed to the maximum because the mining sector not seriously managed; if managed thoughtfully, it can be a potential source of income, and the welfare of the people in the area increases so that unemployment minimized. In general, the purpose of establishing a company is to earn profits, increase sales, maximize the value of shares, and improve the welfare of shareholders. The tight business competition requires companies to develop innovation, improve performance and expand the business so that it continues to survive and compete. Aneka Tambang (Persero) Tbk as a company listed on the Indonesia Stock Exchange, particularly the metals and minerals subsector, its business activities include exploration, exploitation, processing, refining, searching, 
mining (excavation), utilization and marketing of nickel ore, ferronickel, gold, silver, bauxite, coal, alumina, and precious metal refining services.

However, in the last five years, Antam (Persero) Tbk showed a declining financial performance of the company, as seen in the company's financial statements, Antam recorded net sales value in 2014 fell 17\% to Rp.9.42 trillion from Rp. 11.30 trillion compared to the achievements in 2013, while in 2015, Antam's profitability from the nickel operating segment recorded a current year loss of Rp. 465 billion, 197.3\% lower than in 2014. Besides, the writer also took a sample of profit (loss) before tax income in the company's financial statements, wherein 2013 suffered a loss of Rp.132 million, in 2014 losses increased by Rp.775 million and the most massive decline occurred in 2015 amounting to Rp.1,668 billion. Antam (Persero) Tbk faces major obstacles stemming from uncontrolled external conditions due to falling nickel commodity prices due to weakening world economic conditions that have not been encouraging, besides Antam's loss was triggered by a ban on the export of raw minerals by the Government which resulted in no longer selling ore nickel abroad, and nickel ore production is only used as Pomalaa ferronickel ore or sold to domestic consumers.

A made the company's profit decline, as seen from fluctuating closing stock price movements in 2014. Still, until 2015 the share price dropped sharply, which resulted in Antam's declining performance and being unable to provide sufficient capital to fund various planned projects. If the problem goes on and on, it will undoubtedly have an impact on the possibility of PT Antam going bankrupt, which means that Antam has failed in carrying out its operations. Financial statements, according to Kasmir (2014: 07), financial statements are reports that show the company's financial condition at this time or in a certain period. According to Munawir (2012: 02): "Financial statements are the results of the accounting process that can use as a tool to communicate between financial data or activities of a company with those who are interested in the company's data or events. The purpose of the Financial Statements, according to Kasmir (2014: 10), is to provide financial information about a company, both at certain times and at specific periods. Business reports can also be prepared suddenly according to company needs or periodically. Specifically, financial statements can provide financial information to parties inside and outside the company that have an interest in the company.

The types of Financial Statements by (Kasmir, 2014: 28) kinds of financial statements prepared are: a) Balanced sheet is a report that shows the company's financial position on a specific date (a) Income Reports are financial statements that describe the results of company operations in a certain period, (b) the Capital Change Report contains the amount and type of capital currently owned. (c) This report also explains changes in equity and the causes of changes in the capital in the company, (d) Cash Flow Statement is a report that shows all aspects related to company activities, both those that have a direct or indirect influence on cash, (e) Report notes the financial statements are reports that provide information if there are financial statements that require unique explanation.

Financial Ratios According to Kasmir (2014: 104), financial ratios are the activities of comparing numbers in financial statements by dividing one number with another name. Types of Financial Ratios by Habib (2008: 52) financial ratios divided into several groups, namely (a) Liquidity Ratios consist of Current Ratio (CR), and Quick Ratio, (b) Debt ratios include of Total Debt to Total Assets Ratio, Times Interest Earned and Fixed Change Coverage, (c) The activity ratio consists of Inventory Turnover, Average Collection Period, Fixed Assets Turnover and Total Assets Turnover, (d) Profit Ratio consists of Profit Margin On Sales, Return On Assets 
Bankruptcy Prediction Analysis Using the Altman Z-Score Method at PT Aneka Tambang (Persero) Tbk Fitriani, Muniarty

(ROA), Return On Net Worth, (e) Growth Ratio consists of Sales Growth and Net Profit Growth.

Bankruptcy According to Toto, Prihadi (2011: 332), "bankruptcy (bankruptcy) is a condition in which a company is no longer able to pay off its obligations." According to Prihatini, MED \& Sari (2013) argues that Bankruptcy or financial failure occurs when the total liabilities exceed the fair value of the assets or when the current liabilities exceed the existing assets. Meanwhile, according to Gamayuni (2011: 165), bankruptcy is a financial problem that is so severe that the company is unable to run its operations properly.

Indicators of bankruptcy occur because of less competent management. But the leading cause of failure is influenced by various other factors that are often related to one another. According to Rudianto (2013: 252), the origins of failure of a company classified into two, namely:

1. Internal Factors, Mismanagement in finance that can cause company failure, includes (a) The existence of the debt is too large to provide a heavy burden for the company, (b) Current liabilities that are too large above current assets, (c) Late collection of receivables or the number of Bad Debts, (d) (uncollectible receivables) and errors in dividend-policy. Mismanagement in the non-financial sector that can cause company failure includes (a) Error in choosing the place of domicile of the company, (b) Error in determining the product produced, (c) Errors in determining the size of the company and excessive expansion, (d) The lack of a functional organizational structure of the company and mistakes in the selection of company leaders and errors in purchasing, production, and marketing policies.

2. External Factors, Various external factors can be a cause of failure of a company. Foreign objects are various things that come from outside the company and which are outside the power or control of the leadership of the company or business entity, namely (a) macroeconomic conditions, both domestic and international, (b) There is intense competition, (c) Declining demand for products produced, (d) price reduction and so forth.

Altman z-score model According to (Altman 2000: 594), Altman Z-Score is a tool used to predict the level of the bankruptcy of a company by calculating the value of several ratios and then included in a discriminant equation. Altman has combined several rates into prediction models with statistical techniques, namely discriminant analysis used to predict the occurrence of company bankruptcy with the term Z-Score. Z-Score is a score that determined from a standard calculation that will indicate the possibility of insolvency of the company.

In 1984, Altman revised the equation previously made in 1968. This equation made so that this prediction model could not only use in manufacturing companies that went public but could also implicate for non-manufacturing companies. There are five types of financial ratios that can be combined to see the difference between a bankrupt and non-bankrupt company determined by the formula as follows:

$$
\mathrm{Z}=0.717 \mathrm{X} 1+0.847 \mathrm{X} 2+3.107 \mathrm{X} 3+0.420 \mathrm{X} 4+0.998 \mathrm{X} 5 .
$$

Formula :

$\mathrm{X}_{1}=$ Working Capital To Total Assets

$\mathrm{X}_{2}=$ Retained Earnings To Total Assets 
Bankruptcy Prediction Analysis Using the Altman Z-Score Method at PT Aneka Tambang (Persero) Tbk Fitriani, Muniarty

$\mathrm{X}_{3}=$ Earnings Before Interest And Taxes To Total Assets

$\mathrm{X}_{4}=$ Book Value Of Equity To Total Liability

$\mathrm{X}_{5}=$ Sales To Total Assets

Source : (Hanafi, 2015:657)

A. Liquidity Ratio (Working Capital To Total Assets $\left(\mathrm{X}_{1}\right)$.

This ratio measures liquidity by comparing net liquid assets with total assets.

$$
X 1=\frac{W \text { orking Capital }}{\text { Total Assets }}
$$

B. Profitability Ratio (Retained Earnings To Total Assets $\left(X_{2}\right)$. This ratio is a measurement of profitability that detects a company's ability to generate profits.

$$
X 2=\frac{\text { Retained Earnings }}{\text { Total Assets }}
$$

C. Profitability Ratios (Profit Before Interest And Taxes to Total Assets $\left(\mathrm{X}_{3}\right)$.

This ratio has a function to measure the company's ability to generate profits from the assets used or can say as a measure of the productivity of company assets.

$$
X 3=\frac{\text { Profit Before Interest And Taxes }}{\text { Total Assets }}
$$

D. Leverage Ratio (Book Value of Equity to Total Liability $\left(\mathrm{X}_{4}\right)$. This ratio uses to describe the leverage in the form of a company's long-term financial and to find out the amount of company capital used to bear the burden of debt.

$$
X 4=\frac{\text { Book Value of Equity }}{\text { Total Liability }}
$$

E. Performance Ratio (Sales to Total Assets $\left(\mathrm{X}_{5}\right)$.

This ratio measures how efficiently these assets utilized to obtain income from sales. The higher the Total Asset Turn Over means the more efficient use of the overall assets of the company in generating sales volume.

Source: Rudianto (2013:255)

$$
X 5=\frac{\text { Sales }}{\text { Total Assets }}
$$

Criteria for a good and bankrupt company based on the revised Altman Z-Score model values, namely: If $Z>2.99$ classified as a good company. If $Z<1.23$ is classified as a potential bankrupt company, If $Z$ between 1.23 to 2.99 classified as a company in the grey area or Financial distress.

Results of previous studies conducted by (Kokyung \& Khairani, 2013) with the title Altman Z-Score Analysis and Springate to determine the potential for bankruptcy at Bakrie Telecom Tbk in 2009-2012. The results of these studies are companies experiencing significant performance. They reinforced by the results of the Altman Z-Score bankruptcy analysis, which 
Bankruptcy Prediction Analysis Using the Altman Z-Score Method at PT Aneka Tambang (Persero) Tbk Fitriani, Muniarty

showed a state of bankruptcy or serious financial problems in 2012. While the results of the Springate method, the company experienced bankruptcy threats from 2009-2012. The difference in research conducted by (Kokyung \& Khairani, 2013) uses the Altman Z-Score and Springate Variables to assess the potential for bankruptcy at Bakrie Telecom Tbk in 2009-2012 ".

\section{METHOD}

This research uses descriptive research type that is with a quantitative approach. Quantitative analysis is research that concentrates on testing theories through research variables in the form of numbers and then analyzing data by statistical processes both manually and computer software using the SPSS version 16.0 program. The population use financial statement data in the way of a balance sheet consisting on current assets, liabilities, equity, total assets and profit and loss consisting of profit before tax and sales data for ten years from 2009 to 2018 published Indonesia Stock Exchange while the sample in this study Aneka Tambang (Persero) Tbk's financial statements for eight years, which began in 2011 to 2018, a form of a Balance Sheet consisting of Current Assets, liabilities, equity, total assets, and profit and loss data consisting of profit before tax and sales data. The sampling technique used is purposive sampling. Reasons for using Purposive Sampling. Namely, the easily accessible availability of data and the data updates needed in research already listed in the financial report of Aneka Tambang (Persero) Tbk. The data analysis technique used in this study is the analysis technique using discriminant analysis with the Altman Z-Score method and one sample t-test analysis using the SPSS version 16.0 program. Based on data obtained from the financial statements, the Z-Score value at Aneka Tambang (Persero) Tbk experienced fluctuations (increase and decrease) in the period 2011 - 2018, which the following table:

Table 1

Discriminant Analysis with the Altman Z-Score Method with Five Financial Ratios Period 2011-2018

\begin{tabular}{|c|c|c|c|c|c|c|c|}
\hline \multirow[t]{2}{*}{ Tahun } & $\left(\mathrm{X}_{1}\right)$ & $\left(\mathbf{X}_{2}\right)$ & $\left(\mathrm{X}_{3}\right)$ & $\left(X_{4}\right)$ & $\left(X_{5}\right)$ & \multirow{2}{*}{$\begin{array}{l}\text { Z- } \\
\text { Score }\end{array}$} & \multirow[t]{2}{*}{ Category } \\
\hline & 0,717 & 0,874 & 3,107 & 0,420 & 0,998 & & \\
\hline \multirow[t]{2}{*}{2011} & 0,543 & 1,782 & 0,169 & 0,324 & 0,681 & \multirow[t]{2}{*}{3,288} & \multirow[t]{2}{*}{ Good } \\
\hline & 0,389331 & 1,557468 & 0,525083 & 0,13608 & 0,679638 & & \\
\hline \multirow[t]{2}{*}{2012} & 0,234 & 0,596 & 0,198 & 1,384 & 0,530 & \multirow[t]{2}{*}{2,414} & \multirow[t]{2}{*}{ Grey } \\
\hline & 0,167778 & 0,520904 & 0,615186 & 0,58128 & 0,52894 & & \\
\hline \multirow[t]{2}{*}{2013} & 0,147 & 0,538 & $-0,006$ & 0,896 & 0,517 & \multirow[t]{2}{*}{1,449} & \multirow[t]{2}{*}{ Grey } \\
\hline & 0,105399 & 0,470212 & $-0,01864$ & 0,37632 & 0,515966 & & \\
\hline \multirow[t]{2}{*}{2014} & 0,113 & 0,494 & $-0,038$ & 0,842 & 0,427 & \multirow[t]{2}{*}{1,174} & \multirow[t]{2}{*}{ Bankrupt } \\
\hline & 0,081021 & 0,431756 & $-0,11807$ & 0,35364 & 0,426146 & & \\
\hline \multirow[t]{2}{*}{2015} & 0,228 & 0,316 & $-0,055$ & 0,342 & 0,347 & \multirow[t]{2}{*}{0,759} & \multirow[t]{2}{*}{ Bankrupt } \\
\hline & 0,163476 & 0,276184 & $-0,17089$ & 0,14364 & 0,346306 & & \\
\hline \multirow[t]{2}{*}{2016} & 0,209 & 0,323 & 0,008 & 0,101 & 0,304 & \multirow[t]{2}{*}{0,803} & \multirow[t]{2}{*}{ Bankrupt } \\
\hline & 0,149853 & 0,282302 & 0,024856 & 0,04242 & 0,303392 & & \\
\hline \multirow[t]{2}{*}{2017} & 0,115 & 0,325 & 0,015 & 0,705 & 0,422 & \multirow[t]{2}{*}{1,130} & \multirow[t]{2}{*}{ Bankrupt } \\
\hline & 0,082455 & 0,28405 & 0,046605 & 0,2961 & 0,421156 & & \\
\hline \multirow[t]{2}{*}{2018} & 0,090 & 0,318 & 0,038 & 0,686 & 0,758 & \multirow[t]{2}{*}{1,505} & \multirow[t]{2}{*}{ Grey } \\
\hline & 0,065 & 0,277932 & 0,118066 & 0,28812 & 0,756484 & & \\
\hline
\end{tabular}

Source: secondary data processed, 2020 
Bankruptcy Prediction Analysis Using the Altman Z-Score Method at PT Aneka Tambang (Persero) Tbk Fitriani, Muniarty

The framework of thinking in this study is as follows:

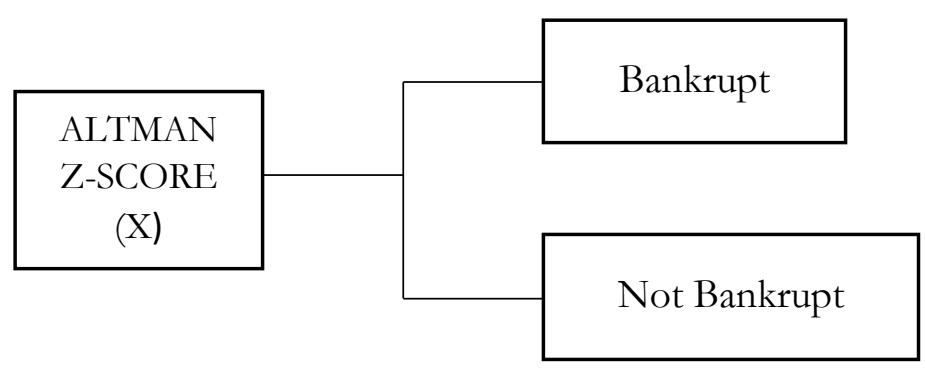

\section{RESULT AND DISCUSSION}

Table 2.

Altman Z-Score Discriminant Calculation Results Period 2011-2018

\begin{tabular}{ccc}
\hline YEAR & $\begin{array}{c}\text { NILAI Z- } \\
\text { SCORE }\end{array}$ & CATEGORY \\
\hline $\mathbf{2 0 1 1}$ & 3,29 & Good \\
\hline $\mathbf{2 0 1 2}$ & 2,41 & grey \\
\hline $\mathbf{2 0 1 3}$ & 1,45 & grey \\
\hline $\mathbf{2 0 1 4}$ & 1,18 & bankrupt \\
\hline $\mathbf{2 0 1 5}$ & 0,76 & bankrupt \\
\hline $\mathbf{2 0 1 6}$ & 0,80 & bankrupt \\
\hline $\mathbf{2 0 1 7}$ & 1,13 & bankrupt \\
\hline $\mathbf{2 0 1 8}$ & 1,51 & grey
\end{tabular}

Source: secondary data processed, 2020

From the above table, is known that the Z-Score value at PT Aneka Tambang (Persero) Tbk has fluctuated; within two years, the company was in the grey area (financial difficulty) category wherein 2012 it was 2.41, and in 2013 it decreased by 1.45. Until 2014 the company suffered losses because of the Z-Score 1.18. In 2015 - 2016 experienced the most massive losses, amounting to $0.76-0.80$, a very high loss compared to 2014, in 2017 the company's performance deteriorated because the company is still in the bankruptcy category until 2018 the company's performance is still in the type of "a grey area" the company is experiencing financial difficulties.

Table 3

Analysis t-test One Sample

One-Sample Test

\begin{tabular}{|c|c|c|c|c|c|c|}
\hline & \multicolumn{6}{|c|}{ Test Value $=2.99$} \\
\hline & \multirow[b]{2}{*}{$\mathrm{t}$} & \multirow[b]{2}{*}{ df } & \multirow[b]{2}{*}{ Sig. (2-tailed) } & \multirow{2}{*}{$\begin{array}{c}\text { Mean } \\
\text { Difference }\end{array}$} & \multicolumn{2}{|c|}{$\begin{array}{l}95 \% \text { Confidence Interval } \\
\text { of the Difference }\end{array}$} \\
\hline & & & & & Lower & Upper \\
\hline Z-Score & -4.640 & 7 & .002 & -1.424750 & -2.15076 & -.69874 \\
\hline
\end{tabular}

Source: SPSS output version 16.0

Based on the tabulation of data with SPSS version 16.0, the results of one-sample t-test with $\mathrm{t}$-value of $=-4,640$ were then compared with the t-table value for the error level of $5 \%$, one-party test, and degrees of freedom $(\mathrm{df})=8-1=7$, then obtained t-table $=1.894$ so that the value of $\mathrm{t}$-count is smaller than the value of $\mathrm{t}$-table $(-4,640<1,894)$. so that the hypothesis Ho is 
Bankruptcy Prediction Analysis Using the Altman Z-Score Method at PT Aneka Tambang (Persero) Tbk Fitriani, Muniarty

accepted and $\mathrm{Ha}$ is rejected, which means "Altman Z-Score value at PT Aneka Tambang (Persero) Tbk is less than 1.23 than expected, and the company has the potential to go bankrupt.

\section{CONCLUSION}

Aneka Tambang (Persero) Tbk's performance has fluctuated, wherein 2012 and 2013 were in the grey area category (financial difficulties), and losses increased in 2014 - 2017 in the bankrupt group, until 2018 the company's performance was the "grey area" category, where the company is experiencing financial difficulties. Aneka Tambang (Persero) Tbk included in the type of potential bankruptcy for four years. Based on calculations using the Altman Z-Score discriminant analysis, shows Aneka Tambang (Persero) Tbk has a bad financial condition, which manifests as having a negative value of less than 1.23 than expected, and the company has the potential bankrupt.

The results of one-sample t-test with a value of $\mathrm{t}$-count $=-4,671$ then the number is compared with the value of the table for the error level of $5 \%$, one-party test, and degrees of freedom $(\mathrm{df})=8-1=7$, then obtained t-table $=1.894$ irritable $(-4,640<1,894)$. which means "The Altman Z-Score value at PT Aneka Tambang (Persero) Tbk is less than 1.23 than expected, and the company has the potential to go bankrupt.

\section{REFERENCE}

Altman, E.I (2000). Predicting Financial Distress Of Companies Revisiting The Z-Score and Zeta Models", Journal of Accounting Research, Empirical Research in Accounting, 23, 24-30.

Anjum, S. (2012). Business Bankruptcy Prediction Model - A Significant Study of Altman's ZScore Model. Asian Journal of Management Research, 213 - 216.

Gamayuni. (2011). "Analisis Ketepatan Model Altman Sebagai Alat Untuk Memprediksi Kebangkrutan". Jurnal Akuntansi dan Keuangan. 6(2), 1-8.

Hartono, A.S. (2014). "Uji Penerapan Model Prediksi Financial Distress Altman, Springate, Ohlson, dan Zmijewski Pada Perusahaan Sektor Keuangan di Bursa Efek Indonesia", Jurnal llmu Manajemen, 2(2), 328-337.

Kasmir. (2014). “Analisis Laporan Kenangan”. Jakarta: Raja Grafindo Persada.

Kokyung, Khairani. (2014) "Analisis Penggunaan Altman z-score dan springate untuk mengetabui potensi kebangkrutan perusabaan pada PT. Bakrie Telecom Tbk". Jurusan Akuntansi STIE MDP.

Moch. Dzulkirom, M.G Wi Endang N.P, (2015). "Analisis Altman (Z-Score) Sebagai Salah Satu Cara Untuk Mengukur Potensi Kebangkrutan Perusahaan. Fakultas Ilmu Administrasi Universitas Brawijaya Malang”, Jurnal administrasi Bisnis (JAB) 25(1), 1-5.

Munawir. (2010). “Analisa Laporan Kenangan”. Edisi Ketiga Belas. Yogyakarta: Liberty.

Novien Rialdy, (2017). "Analisis Prediksi Kebangkrutan Dengan Menggunakan Metode Altman Z-Score Pada PT. Adhi Karya (Persero) Tbk”. Fakultas Ekonomi Dan Bisnis Universitas Muhammadiyah Sumatera Utara. Jurnal kenangan bisnis 9(1), 79-93.

Prihadi, Toto.(2009). "Investiasi Laporan Kenangan dan Analisis Rasio Keuangan”. Jakarta : PPM.

Prihatini, MED \& Sari (2013). Prediksi Kebangkrutan Dengan Model Grover, Altman Z-Score, Springate dan Zmijewski Pada Perusahaan Food And Beverage Di Bursa Efek Indonesia. E-Jurnal Akuntansi Universitas Udayana 5.2 ISSN : 2302-8556, 417-435.

PT.Aneka Tambang (Persero) Tbk (2019). Annual Report, diperoleh tanggal 08 November 2019, dari http://www.antam.com

Rudianto.(2013). Akuntansi Manajemen Informasi Untuk Pengambilan Keputusan Strategis. Jakarta: Erlangga.

Rulandari, N., \& Sudrajat, A. (2017). Financial Ratio (Altman Z score) with Statistic Modelling. Sugiyono. (2012). Metode Penelitian Kuantitatif Kualitatif Dan R\& D. Bandung: Alfabeta. 
Bankruptcy Prediction Analysis Using the Altman Z-Score Method at PT Aneka Tambang (Persero) Tbk Fitriani, Muniarty

Toto, Prihadi.(2011). Analisis Laporan Kenangan Teori dan Aplikasi. Jakarta, Indonesia: PPM.

www.idx.co.id 